\title{
Rumah Rakit Mapping and Substitution Potential of Pontoon EPS Foundation Technology in Palembang City, South Sumatera, Indonesia
}

\author{
Dimas H. Nugraha ${ }^{1}$, Harum I. Mahadma ${ }^{2}$, and Yulianto P. Prihatmaji ${ }^{2, *}$ \\ ${ }^{1}$ Research and Development Office for Human Settlements Technology Applied, Research and \\ Development Agency, Ministry of Public Works and Housing, Indonesia \\ ${ }^{2}$ Department of Architecture, Faculty of Civil Engineering and Planning, Universitas Islam Indonesia
}

\begin{abstract}
Palembang as one of the old town is that passed by the big river in Indonesia has a distinctive Musi river cultural character, that is Rakit Traditional House (Rumah Rakit). Rumah Rakit is located on the banks of the Musi river that divides the city of Palembang. As time passes, Rumah Rakit began to be abandoned because of bamboo and wood material foundation structure has high maintenance. This study would like to see the mapping of Rumah Rakit in Palembang and substitution of floating foundation using Pontoon EPS materials. The units of analysis are Rumah Rakit and Pontoon EPS material. The observation unit is Rumah Rakit location in Musi river area, Palembang. The research approach uses a qualitative approach. The analysis used is descriptive qualitative supported by spatial data for mapping and comparative to subtitition potency floating foundation technology. The result of this study is the Rumah Rakit located in Seberang Ulu I Sub-district, Ulu 1, Ulu 2, Ulu 3, Ulu 4 and Ulu 9 villages. In the Kertapati sub-district Rumah Rakit are located at the Ogan and Musi, Ogan Baru and Tuan Ketang Villages. The Trend of Rumah Rakit in Palembang city is stable, the existence of rumah rakits although decreasing in number, but the current existence amount up to 71 rumah rakits based on manual preliminary survey results in June 2107. It is driven by the factor of need trade, tourism, service and river transportation which is still active until this day. Related to the potential of Pontoon EPS substitution for floating foundation, from the variable of flexibility, maintenance operational, availability, affordability, reliability of the foundation using Pontoon EPS is feasible to be applied in Palembang.
\end{abstract}

\section{Introduction}

Palembang City is located at 2052 '- 30 5' LS and 104037 '- 1040 52' BT has a cultural specialty of the river until the colonial era dubbed the "Venice of the East". When viewed

* Corresponding author: prihatmaji@uii.ac.id 
from the typography of this city has an average height of $+4-12 \mathrm{~m}$ above sea level. The city of Palembang has a composition of $48 \%$ of unlogged land, $15 \%$ of seasonal soil and $35 \%$ of the land inundation. In the hydrology of the city is divided by the Musi River into 2 major parts of the area Seberang Ulu dan Seberang Ilir. Palembang City has 4 major rivers of Musi River (width 250 - 1350 m), Komering River (236 m wide width), Ogan River (211 $\mathrm{m}$ wide width) and Keramasan River (103 m wide width). In addition the city has 108 tributaries (Government of Palembang City, 2016). One characteristic of Palembang city river culture is the raft house. This traditional house is the result of river culture in the Sriwijaya's where the immigrants are prohibited from living in the mainland. The traditional residential technology utilizes a bamboo raft to be the floating foundation of a house standing on it. The existence of the current raft house in the Musi River, Palembang city in a stagnant condition and there is a tendency will be reduced in the future due to reorientation of cultural patterns of society, the decline in quality and expensive material floating.

The purpose of this study is to know the distribution point of existence and number of raft houses/ Rumah Rakit in Musi River, Palembang using map and coordinate point which is divided into 7 zones based on field observation result in 2017, can be seen on fg.1. In addition, this study to know the substitution of floating-circuit technology from traditional bamboo raft technology substituted using EPS (Extended Polystyrene Foam) pontoon technology and the extent of flexibility, operation and maintenance, availability, and reliability of the foundation. The technology is alternative technology to the floating foundation material of an exterior raft house. It is a part of interpretation based on the background of the Indonesia as a maritime country, global warming and land-subsidence issues.

\section{Method}

This study uses qualitative methods, the result of combinations of primary data from field observation and secondary data. The primary data collection method was conducted by the researchers directly through field observations along the Musi River, interviews with the residents of the raft houses and data documentation. Secondary documents were collected by collecting documents related to raft houses. These are previous studies, papers, and regional regulations.

The scope of the study of raft houses is limited to (1) mapping the distribution of houses along the Musi River, Palembang. (2) Analyze typology, structural components, building materials, identify raft house damage and substitute EPS technology on its structure and see how far flexibility, operation and maintenance, availability, and reliability of the foundation.

\section{Result}

\subsection{Rumah Rakit Distribution Map}

The map of Palembang city figure 1 shows the Musi River crossing point in the preliminary survey in June 2017. Starting from the river edge point 1 of Ulu 1 to Kertapati. The area has a number of Rumah Rakits that are still inhabited by indigenous people who are livelihood as traders, ship craftsmen, services and others. The total number of traditional Rumah Rakits points of Palembang based on manual calculations and the Musi River line on July 7 , 2017 amounted to 64 Rumah Rakits. The point of the house can be seen in the map image attached on the next page sheet. 




Figure 1. Rumah Rakits distribution zone in Musi River, Palembang City

Based on figure 2. up to figure 9. show the points of local rumah rakits Palembang (Rumah Rakit).

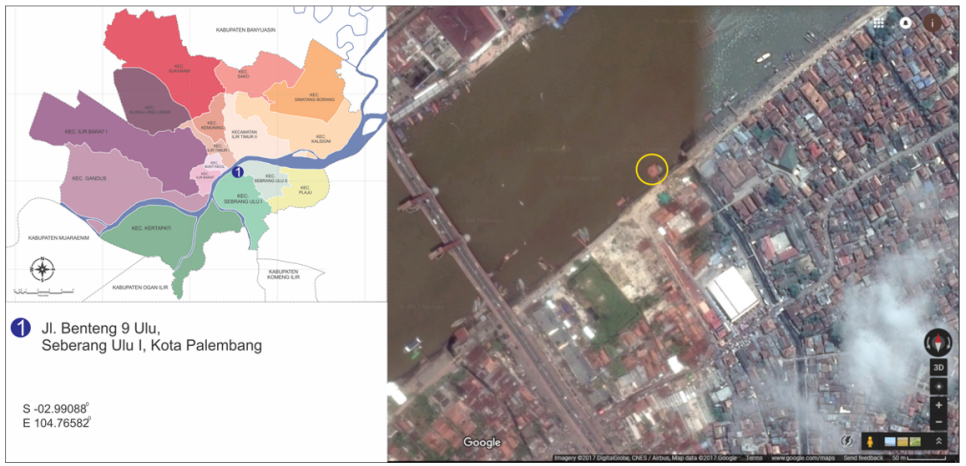

Figure 2. Local Rumah Rakit on Musi river 9 Ulu, Palembang City Source: Balitbang PTP, 2017

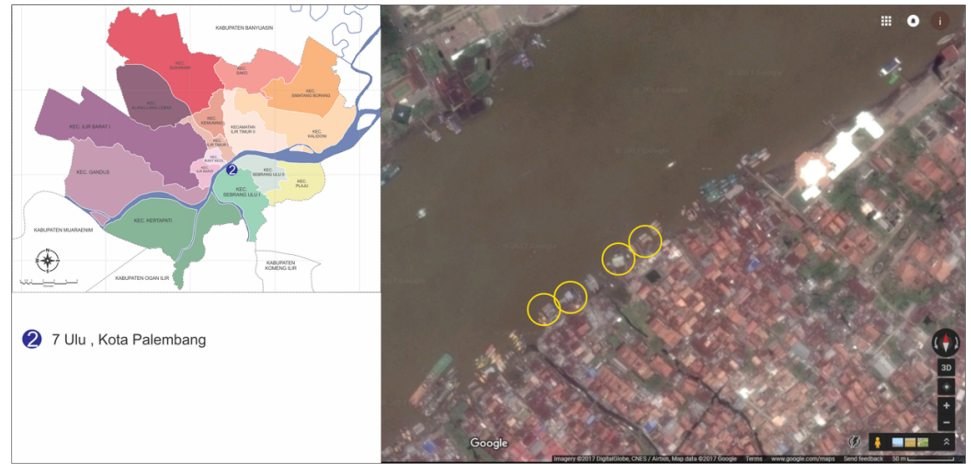

Figure 3. Local Rumah Rakits in the Musi river 7 Ulu, Palembang Source: Balitbang PTP, 2017 


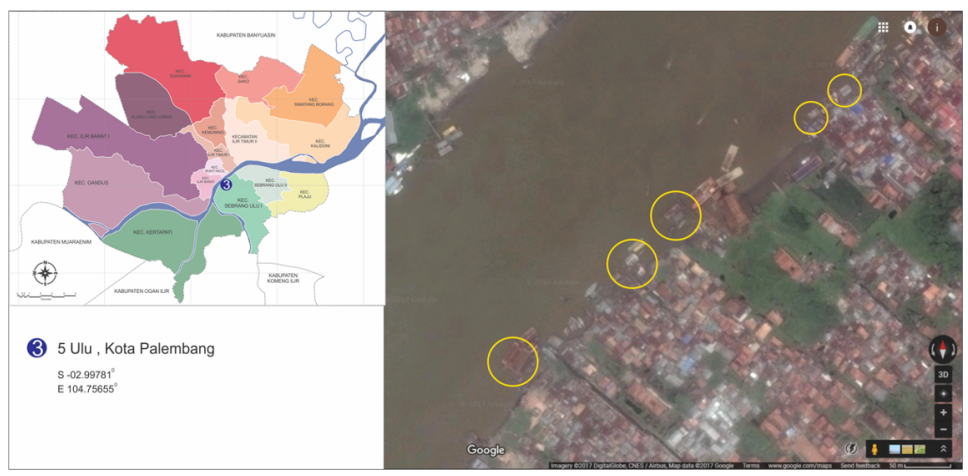

Figure 4. Rumah Rakit in the Musi river 5 Ulu, Palembang City Source: Balitbang PTP, 2017

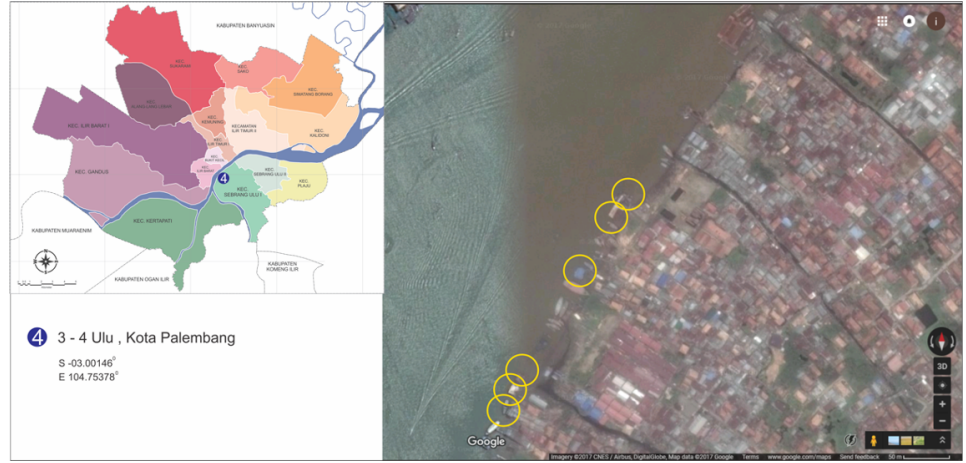

Figure 5. Rumah Rakit in the Musi river 3-4 Ulu, Palembang City Source: Balitbang PTP, 2017

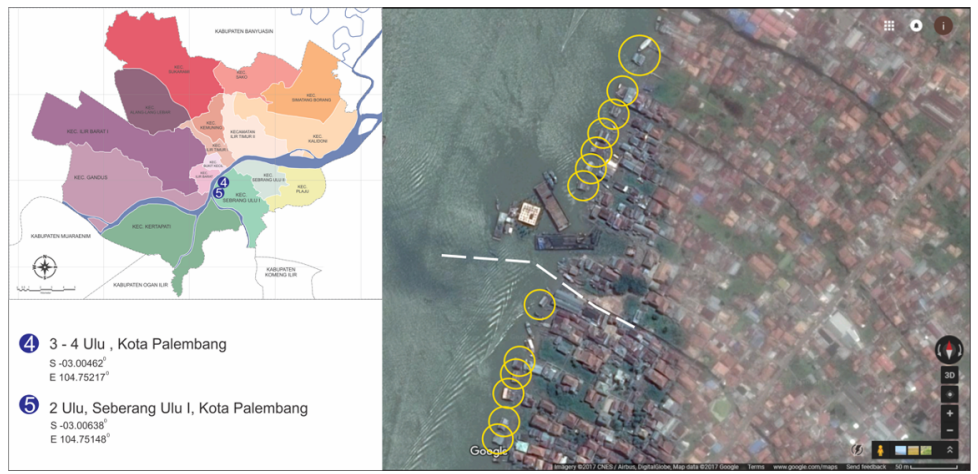

Figure 6. Rumah rakit in the Musi river 5 Ulu, Palembang City Source: Balitbang PTP, 2017 




Figure 7. Rumah Rakit in the Musi river 7 Ulu, Palembang Source: Balitbang PTP, 2017

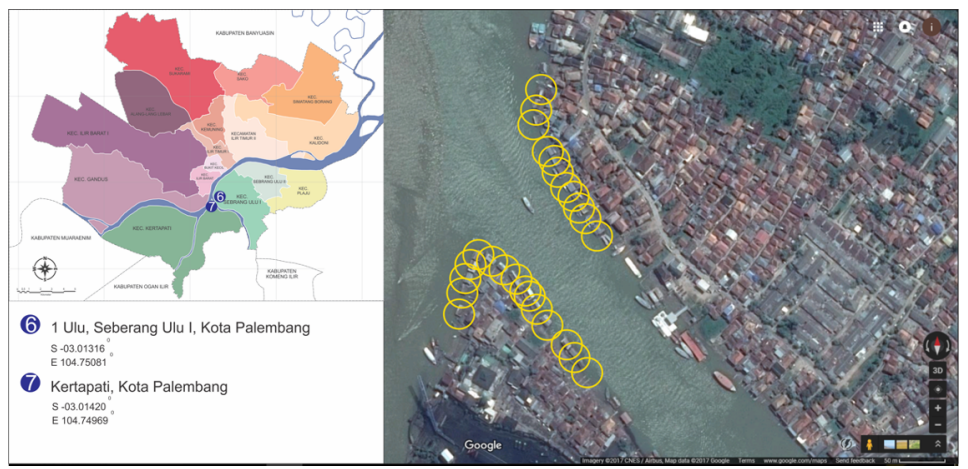

Figure 8. Rumah Rakit in the Musi river 1 Ulu and Kertapati, Palembang City Source: Balitbang PTP, 2017

Based on preliminary survey results in Palembang City with Musi river fringe and validation with map compilation https://www.google.com/maps the number of local rumah rakits in Musi river, Palembang city which is 64 houses which still survive in year 2017.

\subsection{Rumah Rakit Musi River, Palembang}

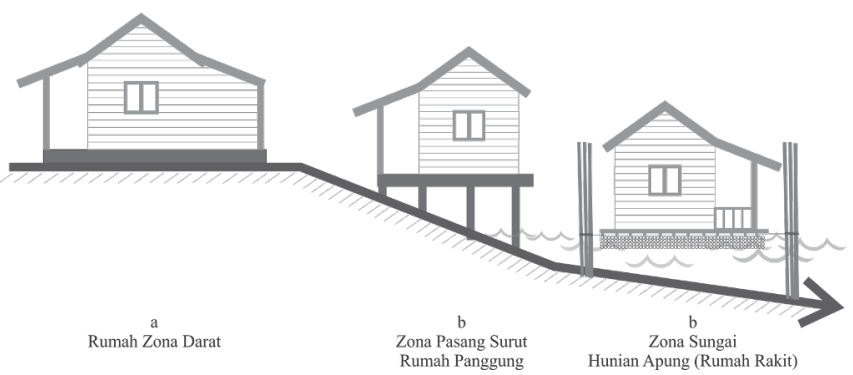

Figure 9. Settlement of Musi river, Palembang

Figure 9. shows the type of existing building in the settlement area of Musi River, Palembang. Land zone homes (a) have building construction like buildings in general that do not have special care. Construction of the building (b) which uses the foundation 
construction of the wooden material used in Ulin wood. Costs incurred for the construction of houses on stilts are initially more expensive than floating buildings, but in its development every 5 years once have to replace the rotten part of bamboo.



Figure 10. Preparation phase of replacement of bamboo floating foundation material of Rumah Rakit, Palembang

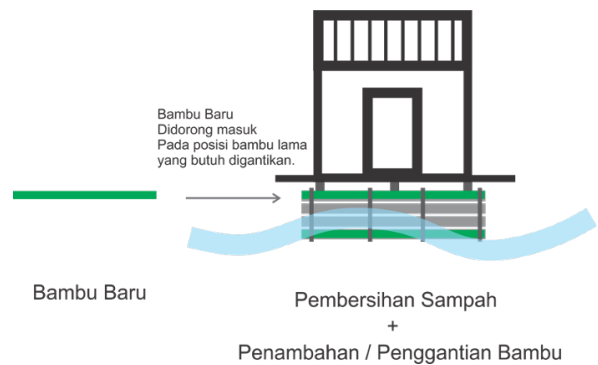

Figure 11. Replacement phase of bamboo floating foundation material of Rumah Rakit, Palembang

The material of the foundation structure of the Rumah Rakit is a structural element that is regularly required to be cleaned every load of garbage that concerns on the bamboo raft has disturbed the stability and balance of the dwelling. Another factor is bamboo material that must be replaced when it weathered, maximum within 5 years done in order to maintain the stability of the floating dwelling in receiving dead or live load on the building. The replacement stage is done after cleaning the floating elements from the garbage, then the next step is the replacement of the rotted bamboo or adding with new bamboo material by pushing the material to the same position with the floating foundation position, the process can be seen in fig.10 and fig. 11 .

\subsection{Characteristic of EPS Pontoon Foundation Technology}

EPS Pontoon is a modular element structure that uses EPS base material. The main component of Expanded Polystyrene (EPS) Foam is styrena $\left(\mathrm{C}_{8} \mathrm{H}_{8}\right)$, derived from petroleum or natural gas and formed by the reaction between ethylene $\left(\mathrm{C}_{2} \mathrm{H}_{4}\right)$ and benzene $\left(\mathrm{C}_{6} \mathrm{H}_{6}\right)$, benzene produced from coal or synthesized from petroleum. Others characteristic from EPS component are density value $15-17 \mathrm{~kg} / \mathrm{m} 3$, termal conductivity $0,036 \mathrm{~W} / \mathrm{mK}$. Pressure strength $85 \mathrm{kPa}$ and absorption 0,5-1,5\%.

Ponton or Modular based EPS can use as a construction structure which floating in the water. Due to the material base of EPS material, then the material will not be damaged due to fresh water, sea water, chemicals, oil, gas, and ultraviolet.

The load capacity per module meter is 5 tons per $\mathrm{kg}$. This Pontoon technology is the result of fabrication that can be applied for various structural and architectural purposes both on land and on water. Having advantages other than environmentally friendly and the dimensions of structural materials can be custom this material has a heat resistance of up to 600. The picture below is an example of an EPS module that has been applied as a floating structure. 


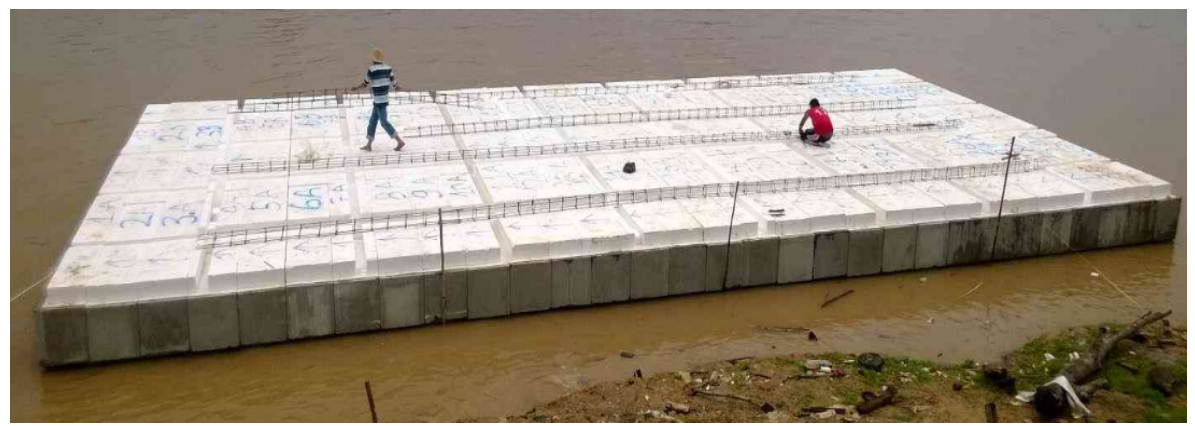

Figure 12. Pontoon Modular EPS

Source: B-Foam, 2017

\section{Discussion}

Table 1. Number of residential floating local Rumah Rakit, Palembang

\begin{tabular}{cc}
\hline Location & $2017^{\text {th }}$ \\
\hline 9 Ulu & 51 \\
7 Ulu & 4 \\
5 Ulu & 5 \\
2 Ulu & 15 \\
$3-4$ Ulu & 13 \\
1 Ulu & 11 \\
Kertapati & 15 \\
\hline total & $\mathbf{6 4}$ \\
\hline
\end{tabular}

Source: Balitbang PTP, 2017.

The total existence of Rumah Rakit in the Musi River, Palembang in July 2017 as many as 64 houses, table 1. Presence must be maintained to preserve the culture of the Musi River in the city of Palembang. Moreover, it can be utilized as tourism object of Musi River by Palembang city government. Based on the data that $52 \%$ of the city of Palembang inundated the need of technology floating foundation structure to become part of technological developments that have basic localities and river culture. Then there are market opportunities in developing technological materials floating technology local Rumah Rakit that can be substituted with pots EPS.

Substitutions in this case are not entirely but may be interchangeable as needed. Comparison of the advantages and disadvantages of traditional material technology characteristics of bamboo material and EPS pontoon material can be seen in table 2 . 
Table 2. Comparison of EPS pontoon technology characteristics with Rumah Rakit local technology

\begin{tabular}{|c|c|c|}
\hline $\begin{array}{c}\text { Characteristic of } \\
\text { Musi River }\end{array}$ & EPS Pontoon & Bamboo raft \\
\hline Tidal $<50 \mathrm{~cm}$ & $\begin{array}{l}\text { EPS pontoon can be used in } \\
\text { waters with a minimum depth } \\
\text { of } 20 \mathrm{~cm}\end{array}$ & $\begin{array}{l}\text { At this time this material is still } \\
\text { used and not constrained }\end{array}$ \\
\hline $\begin{array}{l}\text { Water Content } \\
\text { (Chemistry / liquid } \\
\text { Hydrocarbons) }\end{array}$ & $\begin{array}{l}\text { EPS material cannot attached } \\
\text { liquid carbon hydrocarbons. } \\
\text { Polyethylene coating } \\
\text { technology can used for } \\
\text { finishing EPS Pontoon. So } \\
\text { that material can be used in } \\
\text { the Musi river area. }\end{array}$ & $\begin{array}{l}\text { Bamboo material used at Musi } \\
\text { river that content chemical } \\
\text { waste }\end{array}$ \\
\hline $\begin{array}{l}\text { River is boat } \\
\text { transportation route. } \\
\text { (Ship Crash risk) }\end{array}$ & $\begin{array}{l}\text { Conventional solutions can } \\
\text { used for protection by boat } \\
\text { crash risk. That solution was } \\
\text { utilized rubber tire vehicle. }\end{array}$ & $\begin{array}{l}\text { Conventional solutions can } \\
\text { used for protection by boat } \\
\text { crash risk. That solution was } \\
\text { utilized rubber tire vehicle. }\end{array}$ \\
\hline $\begin{array}{l}\text { Musi river had regular } \\
\text { river dredging } \\
\text { maintenance schedule. }\end{array}$ & $\begin{array}{l}\text { Floating building system using } \\
\text { Pontoon EPS material is } \\
\text { flexible to move in accordance } \\
\text { to the needs }\end{array}$ & $\begin{array}{l}\text { Floating building system using } \\
\text { bamboo floating foundation } \\
\text { material is flexible to move in } \\
\text { accordance to the needs }\end{array}$ \\
\hline $\begin{array}{l}\text { Requirement of } \\
\text { infrastructure floating } \\
\text { building }\end{array}$ & $\begin{array}{l}\text { 1. Solution of black water } \\
\text { and gray water waste using } \\
\text { puskim biofill } \\
\text { 2. Solution of electrical } \\
\text { energy using solar panels }\end{array}$ & $\begin{array}{l}\text { This building not accommodate } \\
\text { the problem of waste water, } \\
\text { electrical energy and clean } \\
\text { water }\end{array}$ \\
\hline $\begin{array}{l}\text { Material impact on the } \\
\text { environment }\end{array}$ & $\begin{array}{l}\text { 1. Ponton EPS is produced } \\
\text { from steorofoam waste in } \\
\text { Bandung } \\
\text { 2. Waste recycle can be } \\
\text { reprocessed by fabrication }\end{array}$ & $\begin{array}{l}\text { 1. Bamboo local natural } \\
\text { products } \\
\text { 2. Bamboo waste can } \\
\text { decompose by natural } \\
\text { processed }\end{array}$ \\
\hline
\end{tabular}

Source: Balitbang PTP, 2017

The system of traditional raft house/ Rumah Rakit structure, Palembang as a whole can be seen in fig.12. Elements of building structures that distinguish from buildings in general that are on land is a kind of foundation. For the foundation elements in the form of wooden frame structure. Selection of materials in this building prioritizes lightweight materials. Fig.13 is an illustrative example of a raft house whose floats are substituted by EPS pontoon. 


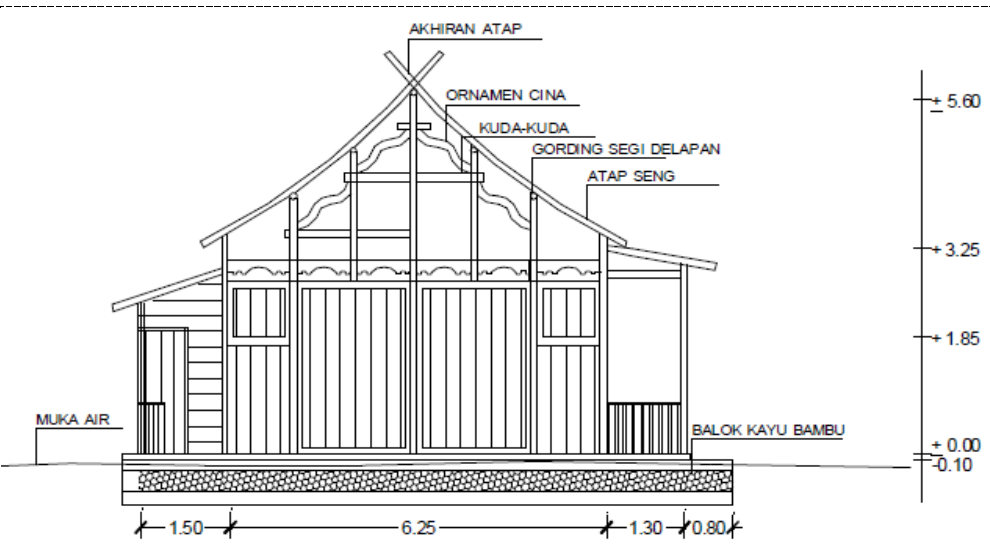

Figure 12. Local technology structure of Rumah Rakit

Source: Budiyuwono, 2016

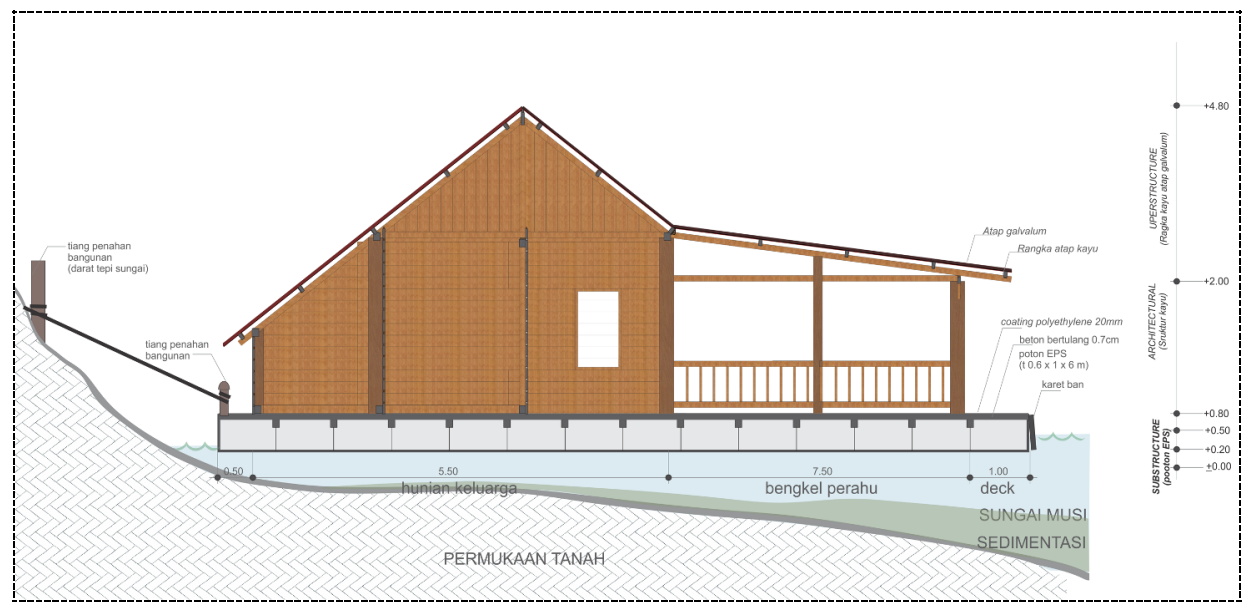

Figure 12. Illustration how Substitution pontoon EPS for floating foundation structure Rumah Rakit Source: Balai PTP, 2017

Related to the flexibility, the material used as the foundation is very flexible to support the function of the building with the area is very varied, so the modification of the floor plan can be very flexible to adjust the space needs of the occupants. The construction of floating pound foundation allows buildings to be erected from various orientations. While the floating foundation of bamboo depends from the direction of the bamboo arrangement. Thus the pontoon foundation is more flexible for the needs of building construction on it.

In terms of affordability, EPS pontoon technology is very flexible to suit the structural needs of the building above. Considering the function and structure of the selected EPS pontoon should be able to accommodate the load character above it. If the building above has a lighter occupant capacity and structure then the EPS Pontoon needs will also change so that the cost per $\mathrm{m} 2$ can be reduced. Raft houses have a lighter building capacity and structure. So the cost will be much more affordable. However, the initial cost of development will indeed be felt larger than the cost of building with the traditional system. But because of the longer duration of the operational costs will be greater pressure. The high cost of initiation for public buildings can be covered with government support, or private sponsors. 
In terms of availability, the technology of floating foundation with bamboo material is still relatively easy to reach and purchased by local communities material. In the aspect of reliability, EPS pottery material ensures a more stable and more durable floating platform. The pontoon foundation material can last up to 30 years without treatment. While bamboo material as a foundation requires maintenance and turnover around 2-5 years. In terms of strength, the pontoon foundation is better able to withstand heavier loads up to 5 tons per $\mathrm{m} 2$. This ability is much more the ability of bamboo raft foundation which is only about $200 \mathrm{~kg} / \mathrm{m} 2$.

\section{Conclusion}

The conclusion of this study is the Rumah Rakit located in Seberang Ulu I Sub-district, Ulu 1, Ulu 2, Ulu 3, Ulu 4 and Ulu 9 villages. In the Kertapati sub-district Rumah Rakit are located at the Ogan and Musi, Ogan Baru and Tuan Ketang Villages. The Trend of Rumah Rakit in Palembang city is stable, the existence of rumah rakits although decreasing in number, but the current existence amount up to 71 rumah rakits based on manual preliminary survey results in June 2107. It is driven by the factor of need trade, tourism, service and river transportation which is still active until this day. Related to the potential of Pontoon EPS substitution for floating foundation, from the variable of flexibility, maintenance operational, availability, affordability, reliability of the foundation using Pontoon EPS is feasible to be applied in Palembang.

\section{Acknowledgment}

This paper is a part of research publication on the appropriate floating technology for building funded by Research and Development Centre on Policy and Application of Technology, Ministry of Public Work and Housing Settlement. Also, some of data using document research grant of International Research Collaboration and Scientific Publication, Ministry of Research, Technology and Higher Education, Indonesia (663/M/KP/XII/2015 and 041/HB-LT/IV/2017).

\section{References}

1. B-Foam Technology.2017. Beton Elemindo Putra, Bandung. Not published

2. Pemerintah Kota Palembang 2016 Geografis Kota Palembang; http://www.palembang.go.id/35/geografis-kota-palembang, 05/23/2018

3. Balitbang PTP (Balai Litbang Penerapan Teknologi Permukoman) 2017 Laporan Akhir Penyian Penerapan Teknologi Struktur Bangunan Rumah (Hunian Apung) (Yogyakarta)

4. Balitbang PTP (Balai Litbang Penerapan Teknologi Permukoman) 2017 Laporan Antara Penyian Penerapan Teknologi Struktur Bangunan Rumah (Hunian Apung) (Yogyakarta)

5. Budiyuwono, Hartanto 2016 "House Typepology of Musi river's Edge in The City of Palembang, South of Sumatra - Indonesia", Depertment of Architecture of Parahyangan Catholic University, Bandung 